\title{
Wybrane ekologiczne aspekty budowy sieci dróg szybkiego ruchu w Polsce
}

\section{Tadeusz Wójcicki}

\section{STRESZCZENIE}

Aspekty ekologiczne są stałym elementem rozważań i działań praktycznych podczas planowania i realizacji głównych dróg krajowych w Polsce. Te zmiany proekologiczne w budownictwie drogowym mają wieloaspektowy charakter, co możemy obserwować na licznych przykładach udanych i mniej udanych realizacji nowych odcinków dróg krajowych.

Celem artykułu jest zbadanie, w jaki sposób zaznacza się wpływ zagadnień ekologicznych na rozbudowę sieci głównych dróg w Polsce i jakie są tego skutki.

Czynniki ekologiczne wpływają przede wszystkim na projektowanie dróg szybkiego ruchu (DSR), albo szerzej, na przygotowanie takich inwestycji do realizacji. Dotyczy to zwłaszcza następujących aspektów: proekologicznego trasowania nowych dróg, budowy przejść dla zwierząt czy ekranów akustycznych. W rzeczywistości dotykają wszystkich aspektów projektowania drogowego, w tym wszystkich branż, ale w każdej branży wpływ jest inny i ma mniejsze albo większe znaczenie. W zakresie sposobu realizacji wielkich inwestycji drogowych wpływ czynników ekologicznych jest mniejszy niż w projektowaniu, ale również się ujawnia, przede wszystkim przez drobiazgowe niekiedy zapisy w decyzjach o środowiskowych uwarunkowaniach.

Z przeglądu ekologicznych aspektów budowy autostrad i dróg ekspresowych wynika, że uwzględnienie ekologicznych wymagań, zawartych zwykle w decyzjach środowiskowych, powoduje znaczący wzrost kosztów realizacji sieci DSR. Koszt ten oszacowano na kwotę ok. 26,0 mld zł, co stanowi ok. 14\% całkowitego kosztu budowy przesądzonej obecnie sieci DSR.

Wśród tych kosztów, największe są związane z budową przejść dla zwierząt, oszacowane na ok. 18,4 mld zł (10\%), w tym budowa samych przejść 14,5 mld zł oraz koszty podniesienia niwelety jezdni głównych ok. 3,9 mld zł. Druga znaczącą grupę kosztów ekologicznych, stanowią koszty związane z proekologicznym wydłużeniem tras drogowych, które oszacowano na 7,6 mld zł (4\%).

Dążąc do ograniczenia tych gigantycznych kosztów zaproponowano zmniejszenie zagęszczenia (czyli zwiększenie rozstawu) projektowanych przejść dla zwierząt w poprzek DSR, co zmniejszyłoby koszty budowy tych obiektów z 18,4 mld zł do ok. 2,8 mld zł bez istotnej zmiany oddziaływań DSR na migrujące zwierzęta. Wtedy największy koszt ekologiczny budowy DSR wiązałby się z wydłużeniem ich tras, a tu można jedynie zalecać inwestorom drogowym, aby nie zgłaszali do procedur środowiskowych takich propozycji wariantów przebiegu drogi, które będą powodować znaczące wydłużenie trasy, przekraczające np. 15\% w stosunku do linii prostej (powietrznej).

Słowa kluczowe: transport, budowa dróg, autostrady, drogi ekspresowe, środowisko

\section{Wstęp}

W ostatnim półwieczu wzrosła znacznie świadomość ekologiczna społeczeństw europejskich, co znalazło swoje odbicie w budowie, praktycznie od podstaw, prawa ekologicznego zarówno na poziomie unijnym jak i krajowym.

Przepisy prawa ekologicznego objęły m.in. sferę działalności budowlanej, w tym budownictwo dróg. W zakresie drogownictwa badania ekologiczne potwierdziły wysoki poziom negatywnego oddziaływania na środowisko dróg o najwyższych klasach 
technicznych. Rozbudowa europejskiej sieci dróg szybkiego ruchu, głównie autostrad, poprzez znaczne nasilenie ruchu drogowego znacząco wpływa zarówno na stan otaczającego środowiska przyrodniczego, jak i warunki życia społeczności lokalnych.

Od początku XXI w. w Polsce realizuje się forsowny program rozbudowy sieci dróg szybkiego ruchu, tj. autostrad i dróg ekspresowych. Największe przyrosty długości tej sieci wystąpiły w ramach realizacji Programu Budowy Dróg Krajowych na lata 2011-2015. Przedtem realizowany był PBDK na lata 2008-2012, a obecnie realizuje się PBDK na lata 2014-2023 (z perspektywą do 2025 r.).

Czynniki ekologiczne wpływają przede wszystkim na projektowanie dróg szybkiego ruchu (DSR), tj. autostrad i dróg ekspresowych, albo szerzej, na przygotowanie tego typu inwestycji do realizacji. Dotyczy to zwłaszcza następujących aspektów: proekologicznego trasowania nowych dróg, budowy przejść dla zwierząt czy ekranów akustycznych. W rzeczywistości dotykają wszystkich aspektów projektowania DSR, w tym wszystkich branż, ale w każdej branży wpływ jest inny i ma mniejsze albo większe znaczenie. W zakresie sposobu realizacji wielkich inwestycji drogowych wpływ ekologii jest mniejszy niż w projektowaniu, ale również się ujawnia, przede wszystkim przez drobiazgowe niekiedy zapisy w decyzjach o środowiskowych uwarunkowaniach.

Celem niniejszego artykułu jest zbadanie, w jaki sposób zaznacza się wpływ zagadnień ekologicznych na projektowanie sieci głównych dróg w Polsce i jakie są tego skutki. Poniżej omówiono szczegółowo proekologiczne modyfikacje projektowania w podziale na kolejne główne branże, tj. na projekt koncepcyjny (wstępny) i projekt drogowy oraz projekty dendrologiczne, mostowe, sanitarne i elektroenergetyczne, a także na końcowy projekt zbiorczy, tj. projekt zagospodarowania terenu (PZT).

\section{Projekt koncepcyjny drogowy}

W tradycyjnym podejściu do projektowania dróg zwykle wykonywano jeden projekt dla jednego przebiegu nowego odcinka drogi, przy czym inwestor - dążąc do minimalizacji kosztów realizacyjnych - wskazywał do realizacji przebieg możliwie najkrótszy, uwzględniając jedynie oczywiste przeszkody terenowe (takie jak góry, rzeki, jeziora, zwarta zabudowa). W rezultacie realizacje drogowe sprzed $2000 \mathrm{r}$. charakteryzował przebieg DSR zbliżony do linii prostej, a wydłużenie nowych tras nie przekraczało zwykle $10 \%$. Widać to na mapie samochodowej Polski, gdzie takie drogi jak tzw. „gierkówka”, czyli dwujezdniowa droga Warszawa - Katowice z lat 70., czy autostrady A-1, A-2 i A-4 wytyczone w latach 90., mają prosty przebieg.

Z początkiem XXI w. sytuacja zmieniła się, gdyż zaczęto uwzględniać nieznane przedtem przeszkody terenowe w postaci obszarów prawnie chronionych, głównie na postawie ustawy o ochronie przyrody, takich jak np. parki narodowe, parki krajobrazowe, obszary chronionego krajobrazu, obszary Natura 2000 czy chronione siedliska przyrodnicze i chronione gatunki roślin, grzybów i zwierząt. Jednocześnie - szukając optymalnego ekologicznie przebiegu 
drogi - wprowadzono wymóg wariantowania przebiegu nowej drogi, a zwykle chodziło o trzy zasadnicze wersje przebiegu DSR, przy czym każdy wariant należało opracować z jednakową dokładnością, nie wyróżniając w tym wariantu preferowanego przez inwestora.

Tabela 1. Proekologiczne lokalne i regionalne wydłużenia tras DSR w PBDK

\begin{tabular}{|c|c|c|c|c|c|}
\hline Lp. & Droga & Miejsce wydłużenia & Główna przyczyna wydłużenia & $\begin{array}{c}\text { Szacunkowe } \\
\text { wydłużenie* } \\
(\mathrm{km})\end{array}$ & $\begin{array}{c}\text { Koszt } \\
\text { wydłużenia** } \\
\text { (mld zł) }\end{array}$ \\
\hline 1. & $A-1$ & Częstochowa & zachodni wariant obwodnicy miasta & 4,6 & 0,138 \\
\hline 2. & $A-1$ & GOP & łamany wariant przejścia przez GOP & 8,2 & 0,246 \\
\hline 3. & $A-2$ & Kałuszyn-Siedlce & ochrona obszaru Natura 2000 & 4,9 & 0,147 \\
\hline 4. & $A-4$ & Balice & krótszy dojazd do lotniska & 4,2 & 0,126 \\
\hline 5. & $A-4$ & Przeworsk-Korczowa & krótszy dojazd do Przemyśla & 8,4 & 0,252 \\
\hline 6. & S-1 & Brzeszcze & ochrona obszaru Natura 2000 & 1,8 & 0,054 \\
\hline 7. & $\mathrm{~S}-3$ & Legnica & zachodni wariant obwodnicy miasta & 3,8 & 0,114 \\
\hline 8. & S-5 & Kościan-Leszno & zachodnie warianty obwodnic miast & 11,8 & 0,354 \\
\hline 9. & S-5 & Bydgoszcz & łamany wariant obwodnicy miasta & 9,6 & 0,288 \\
\hline 10. & S-6 & Płoty-Koszalin & odgięcie drogi do Kołobrzegu & 8,8 & 0,264 \\
\hline 11. & S-6 & Słupsk-Luzino & południowa obwodnica Lęborka & 6,2 & 0,186 \\
\hline 12. & S-7 & Kielce-Jędrzejów & chroniona dolina Nidy & 1,2 & 0,036 \\
\hline 13. & S-8 & Złoczew-Łask & odgięcie drogi do Sieradza & 10,2 & 0,306 \\
\hline 14. & $\mathrm{~S}-8$ & Ostrów M.-Budzisko & Rospuda i Biebrza (zastępcza S-61) & 80,0 & 2,400 \\
\hline 15. & S-10 & Wałcz-Witankowo & ochrona obszaru Natura 2000 & 3,6 & 0,108 \\
\hline 16. & S-11 & Koszalin-Bobolice & ochrona ujęcia wody dla Koszalina & 6,7 & 0,201 \\
\hline 17. & S-11 & Piła-Chodzież & chronione doliny Noteci i Gwdy & 6,6 & 0,198 \\
\hline 18. & S-12 & Chełm-Dorohusk & ochrona obszarów Natura 2000 & 3,9 & 0,117 \\
\hline 19. & S-17 & Garwolin & zachodnia obwodnica miasta & 2,4 & 0,072 \\
\hline 20. & S-17 & Krasnystaw & chroniona dolina Wieprza & 3,2 & 0,096 \\
\hline 21. & S-19 & Białystok-Sokółka & Puszcza Knyszyńska & 19,3 & 0,579 \\
\hline 22. & S-19 & Janów Lubelski & Lasy Janowskie & 6,4 & 0,192 \\
\hline 23. & S-19 & Nisko-Sokołów Młp. & Puszcza Sandomierska & 5,0 & 0,150 \\
\hline 24. & S-19 & Sokołów M.-Rzeszów & przebieg z wykorzystaniem A-4 & 7,7 & 0,231 \\
\hline 25. & S-19 & Strzyżów-Dukla & ochrona obszarów Natura 2000 & 8,9 & 0,267 \\
\hline 26. & S-61 & Szypliszki-Raczki & Puszcza Augustowska & 3,6 & 0,108 \\
\hline 26. & S-61 & Raczki-Szczuczyn & odgięcie drogi do Ełku & 12,7 & 0,381 \\
\hline RAZEM & & & & 253,7 & 7,611 \\
\hline
\end{tabular}

Objaśnienia:

* - liczone jako różnica między przebiegiem wybranym a najkrótszym przebiegiem potencjalnym (odrzuconym)

** - przyjęto szacunkowy koszt jednostkowy budowy DSR w wysokości $30 \mathrm{mln}$ zł za 1 km 
W rezultacie koszty projektowania koncepcyjnego wzrosły średnio trzykrotnie, ale ten wzrost można pominąć w dalszych analizach, gdyż jest niewielki w stosunku do nakładów inwestycyjnych na budowę sieci DSR. Drugi główny skutek wielowariantowości projektu koncepcyjnego jest poważniejszy. Dotyczy przypadków, w których wariant najkrótszy okazuje się w ocenach ekologicznych niekorzystny dla środowiska, co skutkuje wyborem i realizacją wariantu dłuższego albo wręcz najdłuższego. W skrajnym przypadku obwodnicy Augustowa wydłużenie wyniosło 32\%, co oczywiście przełożyło się na odpowiedni wzrost nakładów inwestycyjnych. W innych przypadkach wydłużenie jest mniejsze, a można je łatwo zaobserwować np. na mapach z przesądzonymi przebiegami DSR, wynikającymi z decyzji środowiskowych. Na podstawie analizy takich map w poniższej tabeli zestawiono zidentyfikowane przypadki proekologicznego wydłużenia przebiegów DSR, a następnie na podstawie analizy treści odpowiednich decyzji środowiskowych określono przyczyny wydłużeń i ich szacunkowe skutki finansowe (tabela 1).

Rozbudowa sieci DSR ujęta w PBDK (w okresie 2007-2025) obejmuje budowę około 6070 km odcinków autostrad i dróg ekspresowych. Na podstawie tabeli 1. można przyjąć, że proekologiczne wydłużenie tej sieci będzie stanowić na koniec realizacji aktualnego PBDK ok. $4 \%$ i taki jest $\mathrm{w}$ przybliżeniu wzrost pracochłonności projektowania drogowego, wynikający z aspektu ekologicznego wydłużenia tras DSR.

Inne aspekty ekologiczne mają niewielki wpływ na projektowanie drogowe, ale ujawniają się one dopiero zbiorczo na końcowym etapie prac nad projektem budowlanym drogi, przy scalaniu w jedna, spójną całość wszystkich projektów branżowych, o czym dalej. Na projektantów drogowych, jako podstawową branżę, spada bowiem główny ciężar tego scalania, prowadzącego do opracowania projektu zagospodarowania terenu (PZT).

\section{Projekt dendrologiczny}

Ogólnie rzecz ujmując, projektowanie zieleni przydrożnej nie zmieniło się wiele pod wpływem wymagań ekologicznych. Zawsze przyjmowano, że drogi powinny być obsadzone drzewami i krzewami, choć w różnych projektach nasycenie zielenią pasa drogowego przyjmowano różne. Czasem projektowano dużo zieleni, czasem mało, a zwykle te różnice wynikały ze stosunku inwestora do zieleni, przekładającego się na zatwierdzenie projektu albo z dużą liczbą nasadzeń drzew i krzewów, albo wręcz przeciwnie - z liczbą małą wręcz symboliczną.

Wpływ prawa i procedur ekologicznych na projekty dotyczące zieleni przejawił się zagospodarowaniem przejść dla zwierząt. Organy wydające decyzje środowiskowe kładą wielki nacisk na prawidłowe zagospodarowanie najbliższego otoczenia tych przejść, co ma na celu ułatwienie migracji zwierząt w poprzek drogi i tym samym powiększa skuteczność tych obiektów mostowych. W związku z tym pojawił się nowy typ zieleni, zwany zielenią „ochraniająco-naprowadzającą", który z jednej strony ma naprowadzać zwierzęta w stronę przejścia, a z drugiej ma maskować obiekty drogowe i mostowe, ponieważ sztuczne elementy w przestrzeni odstraszają zwierzęta. Można również ułożyć w przejściu głazy i kłody, 
za którymi zwierzęta mogłyby się ukryć chwilowo, na czas rozpoznawania sytuacji, przed podjęciem następnego etapu wędrówki w poprzek drogi. Pojawiają się nawet takie pomysły, jeszcze niezrealizowane, jak ustawianie na przejściach sztucznych wodopojów dla zwierząt, co wymaga doprowadzenia do nich sieci wodociągowej.

\section{Fot. 1. Węzeł „Bydgoszcz Południe” (dawniej: Fot. 2. Węzeł „Mieleszyn” (dawniej: „Mielno”) "Stryszek") na przecięciu dróg S-5/S-10 i DK- na drodze S-5 koło Gniezna, zrealizowany 25, zrealizowany w ramach PBDK 2008-2012 w ramach PBDK 2014-2023(2025)}

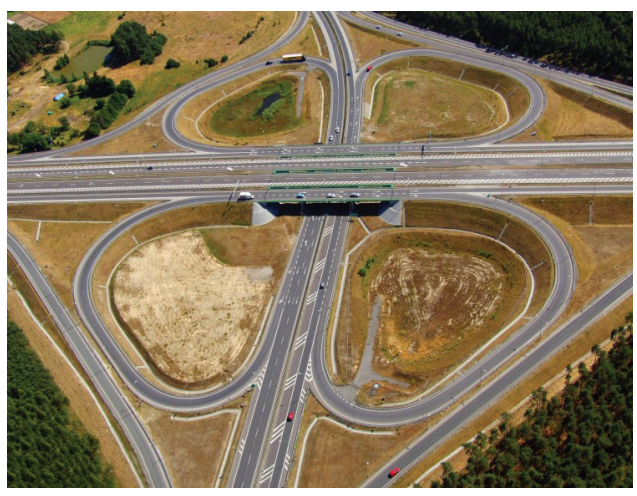

Źródło: GDDKiA

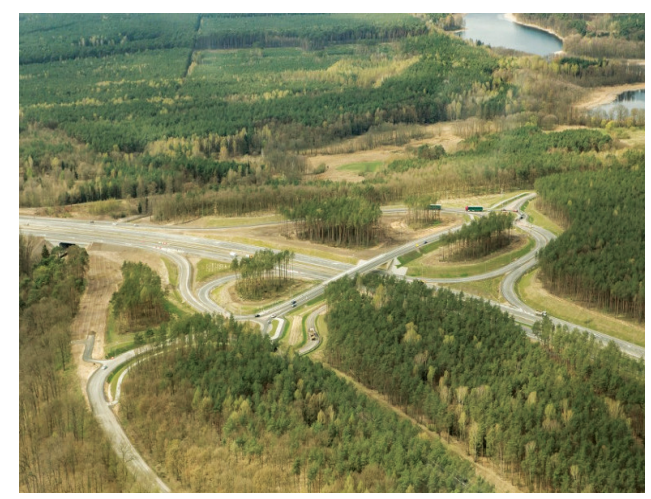

Źródło: GDDKiA

Inny wpływ czynników ekologicznych na projekty zieleni wyraża się w stosowaniu dogęszczeń na skrajach lasów, co jest absolutną nowością w stosunku do okresu „przed-ekologicznego". Odnosi się do nasadzenia w brzegowej strefie lasu przy nowej jego granicy, tworzącej świeżą tzw. „ścianę lasu”. W strefie tej, zwanej fachowo „strefą ekotonową”, wskutek dokonania w sąsiedztwie wycinki lasu pod drogę, poprawiają się warunki świetlne, co umożliwia bujny rozwój podszytu. Zwykle sadzi się tam, między starymi drzewami, sadzonki drzew, które w rezultacie stworzą po latach drugie piętro warstwy najwyższej lasu, zagęszczając tym samym las, jednocześnie niwelując przykry widok świeżej ściany lasu i czyniąc tę strefę brzegową odporniejszą na wiatrołomy. Jeśli droga przecina lasy, to organy ochrony środowiska standardowo wpisują do decyzji środowiskowych warunek dogęszczenia lasu.

W projektach zieleni drogowej nowością z ostatnich lat jest ograniczanie wycinki $\mathrm{w}$ pasach nowo projektowanych dróg do niezbędnego minimum. Dawniej regułą było wycinanie całości lasu, który znalazł się w granicach projektowanego pasa drogowego. Teraz przeprowadza się analizy, czy rzeczywiście trzeba wyciąć las w całości, i jeśli tylko jest możliwość zachowania fragmentu lasu w pasie drogowym, to z takiej możliwości korzysta się.

Dotyczy to zwłaszcza dużych powierzchni wewnętrznych w obrębie węzłów drogowych, zwłaszcza w środku pętli łącznic drogowych, o powierzchniach dochodzących do 1 ha na jedną ćwiartkę węzła. Oszczędza się las, również poza węzłami w przypadku np. odstępu między jezdniami głównymi DSR a drogami do obsługi terenu (serwisowymi) albo przy 
przejściach dla zwierząt lub przejazdach drogowych. O zmianie zasad projektowania $\mathrm{w}$ tej kwestii świadczy porównanie zagospodarowania zielenią węzłów projektowanych w różnym czasie, np. węzła „Bydgoszcz Południe” z całkowitą wycinką lasu, zrealizacja w 2010 r. (fot. 1) z węzłem „Mieleszyn” koło Gniezna z zachowanymi enklawami lasu, realizacja w 2017 r. (fot. 2).

\section{Projekt mostowy}

Oprócz branży drogowej największe zmiany proekologiczne nastąpiły w projektowaniu mostowym (konstrukcyjnym). Można tu mówić wręcz o rewolucji projektowej, gdyż pojawiło się wiele nowych obiektów inżynierskich nieznanych przed „epoką ekologiczną" lub znanych, ale niestosowanych, a obecnie masowo projektowanych i realizowanych [Katalog... 2002; Podręcznik... 2008]. Projektanci mostowi sprostali temu zadaniu, co oznaczało rozszerzenie ich wiedzy zawodowej o zagadnienia ekologiczne i ścisłą współpracę z organami wydającymi decyzje środowiskowe, dotyczące m.in.:

a) przejść dla zwierząt,

b) tuneli przeciwhałasowych,

c) ekranów akustycznych.

Obecnie nikt już nie neguje konieczności stosowania przejść dla zwierząt w poprzek DSR (pod lub nad drogą), ale nadal istnieją spory między inwestorami drogowymi (GDDKiA, koncesjonariusze autostrad) a organami ochrony środowiska, dotyczące kwestii zagęszczenia tych przejść i ich parametrów technicznych [Czudek, Radomski 1981; Madaj, Wołowicki 2003; Jędrzejewski i in. 2004; Jędrzejewski, Ławreszuk 2009]. W przypadku wartości dotyczących parametrów technicznych przejść, inwestorzy z reguły znajdują się na przegranej pozycji, gdyż w rozporządzeniu dotyczącym warunków technicznych dla drogowych obiektów inżynierskich nie ujęto tych parametrów w stopniu dostatecznym (w § 58.2 określono jedynie szerokość minimalną $10 \mathrm{~m}$ pasa przeznaczonego dla ruchu zwierząt pod droga nie precyzując jakiej grupy zwierząt ta szerokość dotyczy), a Generalna Dyrekcja Ochrony Środowiska (GDOŚ) i podległe jej dyrekcje regionalne (RDOŚ) posługują się szczegółowymi wytycznymi zawartymi w Poradniku projektowania przejść dla zwierząt i działań ograniczających śmiertelność fauny przy drogach [Kurek 2011], w którym określono minimalne wymiary przejść przeznaczonych dla różnych grup zwierząt (duże, średnie i małe ssaki oraz płazy).

Wśród tych typów przejść znajduje się w Poradniku typ największy, najkosztowniejszy, nazwany przejściem krajobrazowym (nad drogą), przeznaczony dla wszystkich zwierząt o szerokości minimalnej, z punktu widzenia zwierząt, opcjonalnie $50 \mathrm{~m}$ (tereny nizinne) (fot. 3) albo $200 \mathrm{~m}$ (tunel górski). Najczęściej stosuje się jednak tańsze dolne przejścia dla dużych i średnich zwierząt o szerokości minimalnej odpowiednio $15 \mathrm{~m}$ albo $6 \mathrm{~m}$ (fot. 4 ). Według danych GDDKiA przejście górne krajobrazowe 50 metrowe kosztuje średnio $10 \mathrm{mln}$ zł, przejście dolne dla dużych zwierząt - $5 \mathrm{mln}$ zł, przejście górne dla średnich zwierząt - 4 $\mathrm{mln}$ zł (fot. 5), a przejście dolne dla średnich zwierząt - 2 mln zł. Najtańsze są przepusty pod drogą dla zwierząt małych i płazów - 0,25 mln zł. (fot. 6). 
Badania migracji zwierząt wzdłuż zrealizowanych już różnych typów przejść dla zwierząt wskazują że parametry techniczne określono w Poradniku prawidłowo, a przyjęcie niższych prowadziłoby do znaczącego zmniejszenia skuteczności. Wyjątkiem są tu prawdopodobnie przepusty dla płazów, dla których przyjęto minimalne wymiary 1,00x0,75 m (szerokość x wysokość), czyli niewiele mniejsze niż dla małych zwierząt (1,5x1,5 m), podczas gdy zagraniczne realizacje wskazuja że odpowiednią skuteczność mają prostokątne przejścia dla płazów o wymiarach 0,3×0,3 m albo przejścia rurowe o średnicy 0,4 m. Korekta Poradnika w tym zakresie, nie zgłoszona jednak przez GDDKiA, pozwoliłaby zmniejszyć koszt jednostkowy przejścia dla płazów do ok. 0,005 mln zł, czyli do poziomu pomijalnego w kosztorysach szacunkowych, jeśli chodziłoby tylko o jedno przejście. Jednak w wielu zadaniach inwestycyjnych liczba projektowanych przejść dla płazów dochodzi do kilkudziesięciu, co sumarycznie stanowi już poważny koszt.

W drugiej kwestii, zagęszczenia przejść, inwestor jest w stanie łatwo obalić podane w Poradniku optymalne rozstawy przejść różnych typów wzdłuż drogi, gdyż u ich podstaw leży kosztowna zasada, że nowo wybudowa droga nie może w ogóle ograniczać swobody ruchu

Fot. 3. Przejście górne dla dużych zwierząt
na drodze S-3 w Popowie koło Skwierzyny

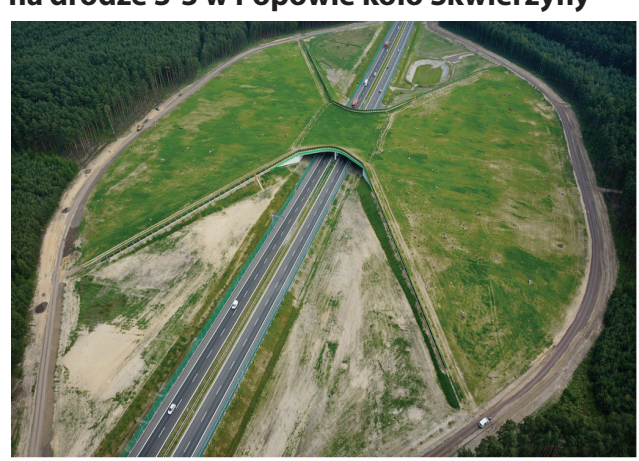

Źródło: GDDKiA

Fot. 5. Przejście górne dla średnich zwierząt na autostradzie A-2 w Izabelinie koło Konina

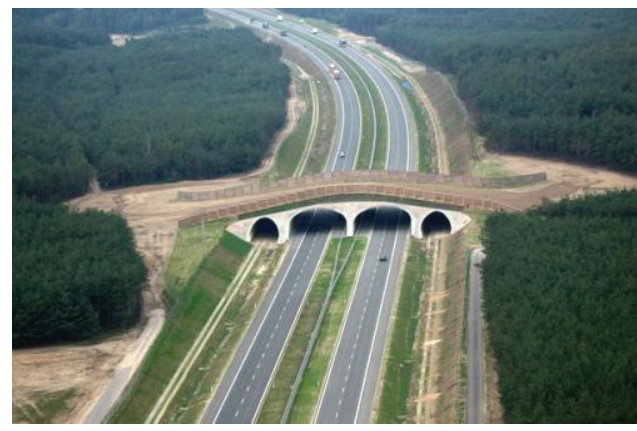

Źródło: GDDKiA
Fot. 4. Przejście dolne dla dużych zwierząt na autostradzie A-1 w Koziarach koło Tczewa

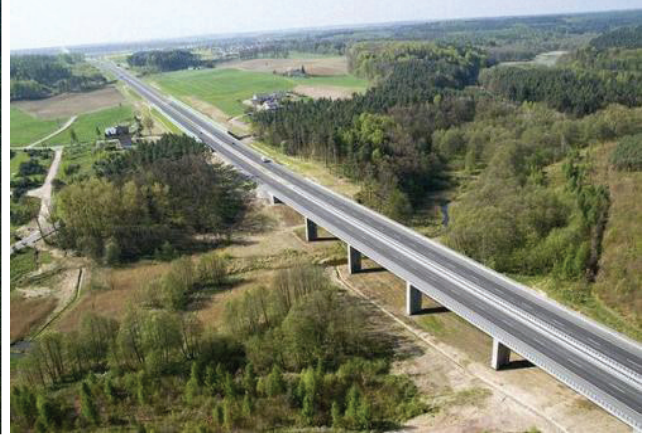

Źródło: GDDKiA

Fot. 6. Przykład przepustu dla małych zwierząt i płazów

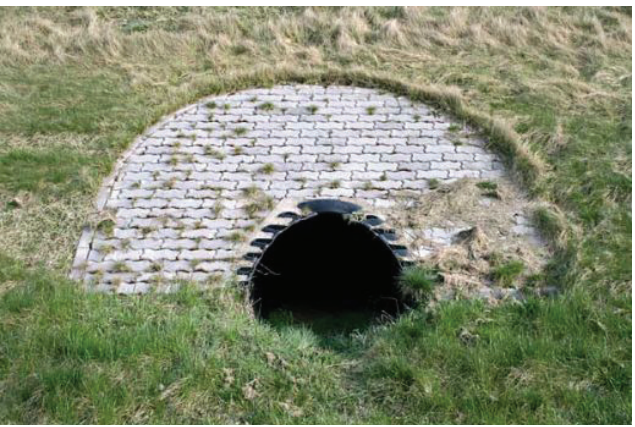

Źródło: GDDKiA 
zwierząt. To tak jakby zagęszczać przejścia dla pieszych przez ulicę do poziomu optymalnego dla nich, np. co $50 \mathrm{~m}$ albo jeszcze mniej. Tymczasem zwierzęta łatwo akceptują znaczne ograniczenia w ruchu w poprzek drogi, byleby tylko istniała co najmniej jedna możliwość przejścia w ramach każdego szlaku migracyjnego.

Oznacza to, że podane w Poradniku rozstawy można znacząco zwiększyć. I tak, zamiast rozstawu średniego co 1,5 km dotyczącego przejść dla dużych zwierząt (w obrębie korytarza migracji) można stosować tylko jedno przejście tego typu w jednym korytarzu. W przypadku przejść dla średnich zwierząt można zwiększyć rozstaw z $1 \mathrm{~km}$ do $3 \mathrm{~km}$ i ograniczyć ich lokalizację wyłącznie do obszarów leśnych (gdzie jest najwyższe zagęszczenie ich populacji), a w przypadku małych zwierząt przyjąć zasadę, że w obszarach leśnych przejścia dla nich zagęszczą przejścia dla większych zwierząt w proporcji 1:1, czyli jedno PZM zostanie wstawione między nie (rozstaw teoretyczny co 1,5 km). W przypadku płazów rozstaw minimalny można zwiększyć z 50-100 m do jednolicie 100 m (tylko w obszarach migracji płazów). W poniższej tabeli zestawiono proponowane zmiany w standardowych rozstawach przejść (tabela 2).

Tabela 2. Proponowane zmiany w maksymalnych rozstawach przejść dla zwierząt przez DSR

\begin{tabular}{|c|l|c|c|c|c|}
\hline Lp. & \multicolumn{1}{|c|}{ Typ obszaru } & $\begin{array}{c}\text { Rozstaw PZD } \\
\text { N1/N2 } \\
(\mathrm{km})\end{array}$ & $\begin{array}{c}\text { Rozstaw PZŚ } \\
\text { N1/N2 } \\
(\mathrm{km})\end{array}$ & $\begin{array}{c}\text { Rozstaw PZM } \\
\text { N1/N2 } \\
(\mathrm{km})\end{array}$ & $\begin{array}{c}\text { Rozstaw PP } \\
\text { N1/N2 } \\
(\mathrm{km})\end{array}$ \\
\hline 1. & Korytarz ekologiczny (migracyjny) & $1,5 /(1 \mathrm{szt})$ & $1 / 3$ & $0,5 / 1,5$ & \\
\hline 2. & Obszar leśny & $3 / 0$ & $1 / 3$ & $0,5 / 1,5$ & \\
\hline 3. & Mozaika polno-leśna & $5 / 0$ & $2,5 / 3$ & $0,5 / 1,5$ & \\
\hline 4. & Obszar polny & $0 / 0$ & $3 / 0$ & $1 / 0$ & \\
\hline 5. & Obszar zabudowy & $0 / 0$ & $0 / 0$ & $1 / 0$ & \\
\hline 6. & Obszar masowych migracji płazów & & & & $0,05 / 0,1$ \\
\hline 7. & Obszar sporadycznych migracji płazów & & & & $0,1 / 0,1$ \\
\hline
\end{tabular}

Objaśnienia:

PZD - przejście dla zwierząt dużych; PZŚ - przejście dla zwierząt średnich;

PZM - przejście dla zwierząt małych; PP - przejście dla płazów

N1 - rozstaw zgodny z wytycznymi GDOŚ [Kurek 2011]

N2 - rozstaw wg ww. propozycji rozgęszczenia przejść

Takie rozgęszczenie przejść przyniosłoby znaczące oszczędności w kosztach ich realizacji, a przy tym oddziaływanie na populacje zwierząt nie byłoby znaczące. $W$ poniższej tabeli oszacowano koszt całkowity tych oszczędności, biorąc pod uwagę obszary kolizji DSR z korytarzami migracyjnymi, lasami oraz z obszarami rolniczymi i zabudowanymi (tabela 3).

Z tabeli 3. wynika, że przy ww. założeniach różnicę w sumarycznych kosztach realizacji przejść dla zwierząt między opcją GDOŚ a opcją oszczędnościowa, można szacować na ok. 11,7 mld zł. Jest to koszt większy (o 4,1 mld zł) niż wyliczony wcześniej koszt związany z proekologicznym wydłużeniem sieci DSR. Nie jest to koszt pełny, bo nie uwzględniono w nim DSR o nieustalonych jeszcze przebiegach (np. S-10, S-11 lub S-74) albo nieuwzględnionych w PBDK (np. S-16 lub S-65). 


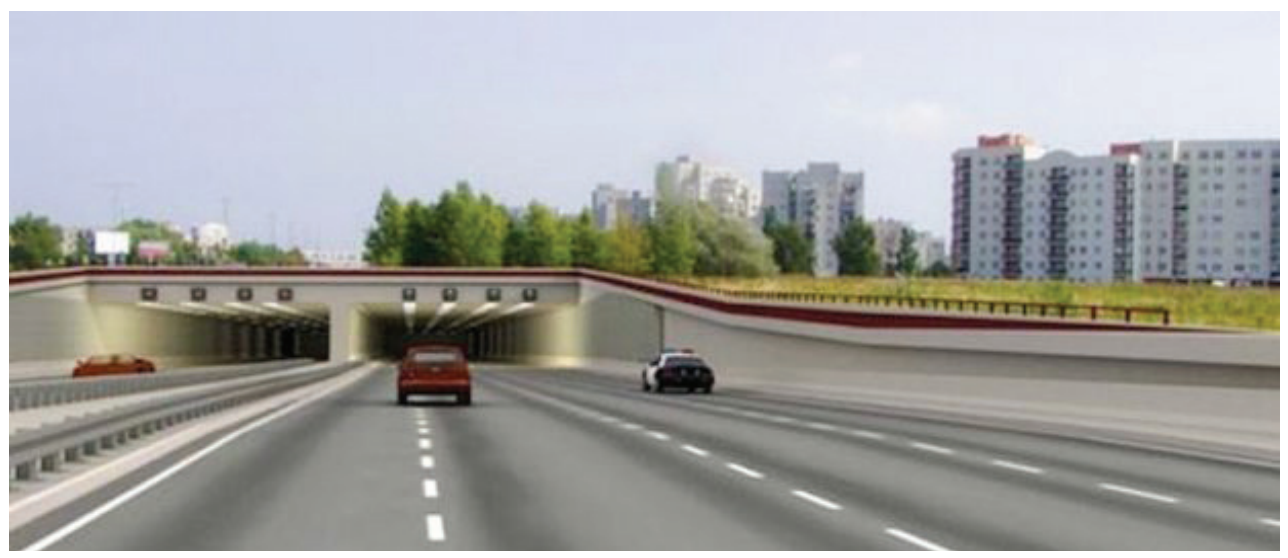

Źródło: GDDKiA

Powyższa propozycja ma na celu zmniejszenie kosztów korzystne z punktu widzenia inwestora, ale niekorzystne dla populacji zwierzęcych. Trzeba jednak wziąć pod uwagę fakt, że inwestor realizuje zadania publiczne korzystne dla społeczeństwa Polski, czyli próbuje rozwiązać konflikt pojawiający się pomiędzy interesami człowieka a dobrem świata zwierzęcego. Nie można preferować opcji faunistycznej kosztem ludzi, co ma miejsce obecnie, lecz doprowadzić do równowagi, do czego prowadzi ww. propozycja.

Tunele przeciwhałasowe i ekrany akustyczne są stosowane w celu ochrony okolicznej zabudowy przed hałasem drogowym, który w przypadku DSR zawsze przekracza normy, przy czym tunele są jedynym skutecznym środkiem tłumiącym hałas w przypadku wysokiej zabudowy, tak jak np. na warszawskim Ursynowie przy drodze S-2 (fot. 7). Dla niskiej zabudowy można z powodzeniem stosować znacząco tańsze ekrany akustyczne, przy czym ich niezbędną wysokość ustala się w specjalistycznych analizach akustycznych.

Obecnie już nikt nie neguje konieczności stosowania takich urządzeń przeciwhałasowych. Do tej pory uważano, że podstawowym urządzeniem jest tu ekran akustyczny. Ostatnio są podejmowane próby zastąpienia ich wałami ziemnymi, ale przeprowadzone analizy wskazuja że takiezastąpienienie powodujeobniżkiłącznychnakładów inwestycyjnych, główniedlatego, że koszty wałów przeciwhałasowych są porównywalne z kosztami ekranów akustycznych, jeśli w rachunku kosztów uwzględni się koszt dodatkowego zajęcia terenu pod wały.

W przypadku tuneli również nie można uzyskać oszczędności w nakładach inwestycyjnych, gdyż ich zastosowanie wynika z przejścia DSR przez wysoką zabudowę. Można odsunąć drogę poza tę zabudowę, ale to wiąże się z reguły z wydłużeniem trasy, a więc z dodatkowymi kosztami niwelującymi zysk wynikający z rezygnacji z tunelu. Takie wydłużenie jest ponadto niekorzystne z punktu widzenia funkcjonalności DSR, bo przecież te drogi mają służyć obsłudze ruchu międzymiejskiego, więc nie można ich odsuwać daleko poza miasta. 


\begin{tabular}{|c|c|c|c|c|c|c|c|c|c|c|c|c|}
\hline 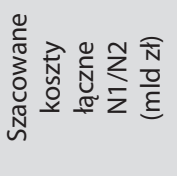 & 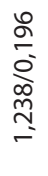 & $\begin{array}{l}\stackrel{0}{m} \\
\text { ò } \\
\stackrel{\text { }}{\alpha} \\
\stackrel{0}{0}\end{array}$ & 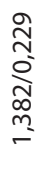 & $\begin{array}{l}\infty \\
\stackrel{0}{0} \\
\vdots \\
\frac{0}{0} \\
0 \\
0\end{array}$ & $\begin{array}{l}\overline{8} \\
0 \\
0 \\
0 \\
0 \\
0 \\
0\end{array}$ & $\begin{array}{l}0 \\
0 \\
0 \\
o \\
\vdots \\
\sigma \\
\\
0\end{array}$ & $\begin{array}{l}\text { o } \\
0 \\
0 \\
0 \\
\infty \\
\stackrel{0}{0} \\
0\end{array}$ & 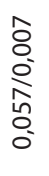 & 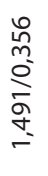 & 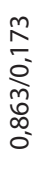 & $\begin{array}{l}\bar{m} \\
\overline{0} \\
o \\
\frac{1}{0} \\
\text { o }\end{array}$ & $\begin{array}{l}8 \\
\frac{8}{0} \\
\frac{1}{2} \\
\\
-\end{array}$ \\
\hline 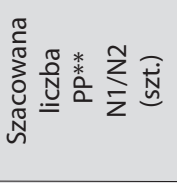 & 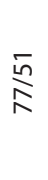 & $\frac{n}{n}$ & $\begin{array}{l}\text { ঃ } \\
\text { ঃ }\end{array}$ & $\stackrel{\sim}{\mathrm{m}}$ & $\underset{m}{N}$ & $\stackrel{\mathrm{N}}{\mathrm{N}}$ & $\frac{0}{i n}$ & $\underset{m}{N}$ & 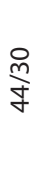 & $\frac{\bar{m}}{\dot{b}}$ & $\underset{\substack{\infty \\
\dot{\sigma}}}{\sim}$ & 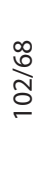 \\
\hline 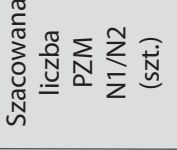 & 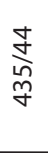 & 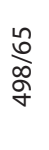 & 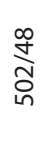 & ลั & $\stackrel{\circ}{\infty}$ & 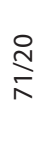 & $\underset{\bar{\sigma}}{\bar{\sigma}}$ & 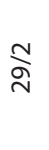 & 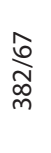 & $\begin{array}{l}\bar{m} \\
\underset{\infty}{\infty} \\
\underset{N}{ }\end{array}$ & 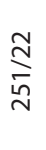 & $\begin{array}{l}\bar{m} \\
\stackrel{2}{o} \\
\stackrel{\sigma}{q}\end{array}$ \\
\hline 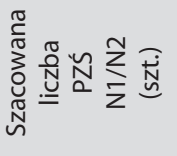 & $\begin{array}{l}\text { ñ } \\
\text { Oे } \\
\text { }\end{array}$ & 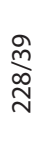 & 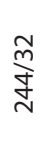 & $\underset{\infty}{N}$ & ㅇํํ & 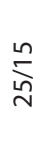 & $\frac{\circ}{b}$ & $\tilde{\sigma}$ & 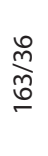 & $\stackrel{\stackrel{n}{\Sigma}}{\underset{N}{N}}$ & $\stackrel{\sigma}{\sigma}$ & $\underset{\Sigma}{\bar{N}}$ \\
\hline 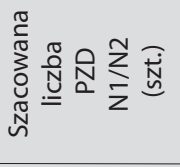 & $\frac{\mathfrak{N}}{\text { f }}$ & 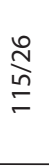 & $\frac{0}{i}$ & $\stackrel{\rho}{f}$ & $\stackrel{\circ}{\circ}$ & $\stackrel{n}{\frac{n}{\sigma}}$ & $\underset{n}{\hbar}$ & $\stackrel{゚}{\curvearrowright}$ & $\frac{\bar{m}}{\sigma}$ & $\frac{0}{i}$ & $\sum_{m}^{m}$ & ָे \\
\hline 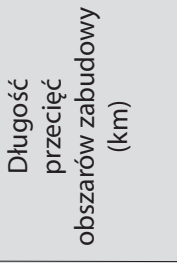 & $\stackrel{\llcorner}{2}$ & $\infty$ & $\stackrel{ \pm}{\sim}$ & $N$ & 0 & - & $\bar{\sim}$ & $\simeq$ & 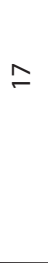 & in & in & ஜे \\
\hline 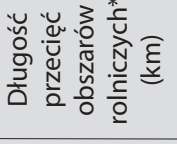 & $\stackrel{\infty}{\underset{\gamma}{ }}$ & $\bar{f}$ & ஓু & $\stackrel{\llcorner}{\sim}$ & $\stackrel{\bullet}{\circ}$ & $\stackrel{m}{\square}$ & ఫ & $\stackrel{\bullet}{\square}$ & $\stackrel{\mathfrak{d}}{\sim}$ & $\stackrel{\leftrightarrow n}{n}$ & $\stackrel{\infty}{\stackrel{\infty}{~}}$ & $\begin{array}{l}\text { : } \\
\text { in }\end{array}$ \\
\hline 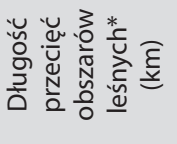 & 이 & fo & ঐ & - & - & 0 & ণ & 0 & F & $\stackrel{\Omega}{\sigma}$ & $\stackrel{\tilde{N}}{\sim}$ & $\stackrel{m}{m}$ \\
\hline 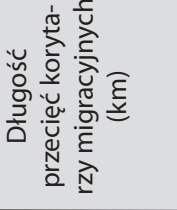 & $\widetilde{\sigma}$ & 음 & i̊ & 0 & 0 & $\overline{6}$ & $\stackrel{m}{\sim}$ & 0 & $\stackrel{\infty}{\sim}$ & $\stackrel{\wedge}{\text { N }}$ & $\forall$ & $\stackrel{\infty}{n}$ \\
\hline $\begin{array}{l}\text { ర్ } \\
\text { ㅁํ }\end{array}$ & $\overline{<}$ & $\underset{<}{\kappa}$ & ${ }_{4}^{+}$ & 安 & 京 & $\frac{\infty}{\frac{1}{4}}$ & $\bar{n}$ & $\tilde{n}$ & in & 望 & ì & in \\
\hline
\end{tabular}




\begin{tabular}{|c|c|c|c|c|c|c|c|c|c|}
\hline 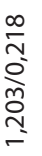 & 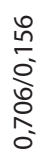 & $\begin{array}{l}\hat{0} \\
0 \\
0 \\
\delta \\
0 \\
0\end{array}$ & 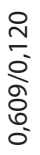 & 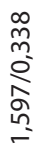 & 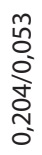 & $\begin{array}{l}\frac{\sigma}{2} \\
0 \\
0 \\
\frac{0}{\alpha} \\
0 \\
0 \\
0\end{array}$ & $\begin{array}{l}\bar{c} \\
\overline{0} \\
0 \\
0 \\
0 \\
0 \\
0\end{array}$ & 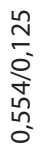 & 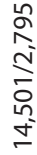 \\
\hline$\frac{\substack{0 \\
\infty \\
0}}{2}$ & 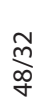 & $\sum_{i n}^{m}$ & 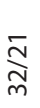 & f & $\sum_{n}^{m}$ & $\sum_{i n}^{m}$ & $\sum_{i n}^{m}$ & 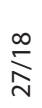 & 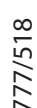 \\
\hline$\frac{\mathcal{I}}{\stackrel{\mathcal{m}}{o ̛ ~}}$ & 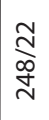 & $\underset{\mathrm{N}}{\mathrm{N}}$ & 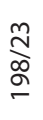 & 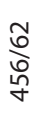 & $\frac{\vartheta}{\vartheta}$ & $\underset{\stackrel{m}{o}}{\stackrel{m}{\nu}}$ & $\underset{\text { D }}{N}$ & 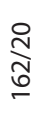 & 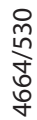 \\
\hline 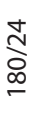 & 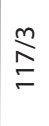 & $\underset{m}{\stackrel{N}{m}}$ & $\underset{\sigma}{\stackrel{n}{z}}$ & 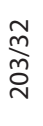 & $\stackrel{\Delta}{\sigma}$ & $\underset{\Xi}{\Xi}$ & $\Xi$ & $\underset{N}{\grave{N}}$ & $\begin{array}{l}\underset{N}{N} \\
\underset{N}{N} \\
\stackrel{N}{N}\end{array}$ \\
\hline 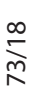 & $\stackrel{\substack{\infty \\
m}}{m}$ & $\stackrel{?}{\text { స }}$ & $\underset{m}{\stackrel{\circ}{m}}$ & \begin{tabular}{l}
$\stackrel{\wp}{m}$ \\
\multirow{f}{\mp}{} \\
$=$
\end{tabular} & 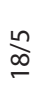 & $\frac{N}{\sigma}$ & $\bar{\gamma}$ & $\frac{m}{\frac{m}{m}}$ & $\frac{\stackrel{\infty}{N}}{\stackrel{\infty}{\delta}}$ \\
\hline$\stackrel{\searrow}{\sim}$ & $\sigma$ & in & $\therefore$ & $a$ & 0 & 0 & $\wedge$ & - & ஜ \\
\hline $\begin{array}{l}\stackrel{\infty}{m} \\
m\end{array}$ & $\underset{\stackrel{\infty}{\sim}}{\sim}$ & $\stackrel{\infty}{\sim}$ & $\stackrel{શ}{\Sigma}$ & ஓ্লি & $\stackrel{\bullet}{\sim}$ & $\stackrel{\Perp}{\sim}$ & $\stackrel{\Perp}{\sim}$ & 오 & $\frac{\sigma}{\tilde{m}}$ \\
\hline$\stackrel{+}{m}$ & 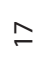 & 0 & $\stackrel{\infty}{N}$ & $\bar{m}$ & $\sim$ & 0 & - & 0 & 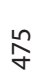 \\
\hline สૅ & $\stackrel{\infty}{q}$ & 0 & $\bar{q}$ & $\stackrel{\circ}{\llcorner}$ & $\stackrel{\gtrless}{\sim}$ & $a$ & in & 织 & $\underset{\Xi}{\Xi}$ \\
\hline 京 & $\stackrel{N}{\tilde{n}}$ & $\frac{\Delta}{\dot{n}}$ & $\overline{\bar{n}}$ & $\frac{a}{\bar{n}}$ & $\underset{\sim}{\sim}$ & 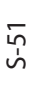 & $\begin{array}{l}\hat{N} \\
\text { ñ }\end{array}$ & $\begin{array}{l}\bar{\phi} \\
\dot{\nu}\end{array}$ & 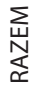 \\
\hline
\end{tabular}

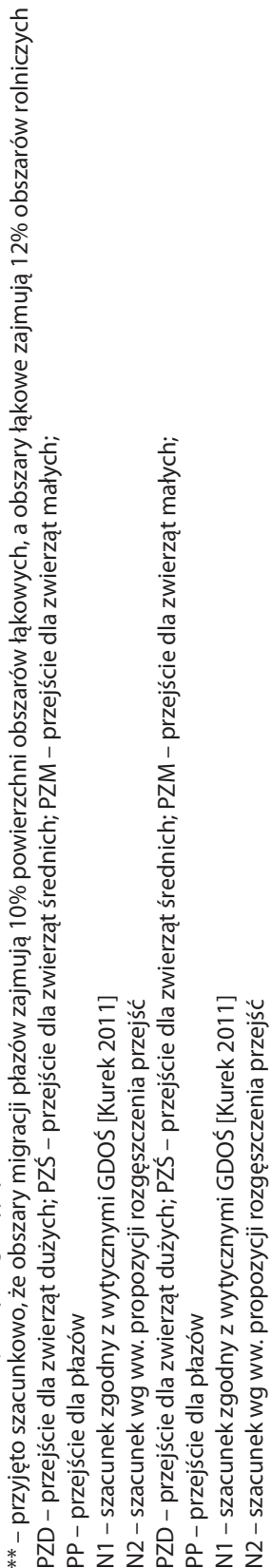




\section{WYBRANE EKOLOGICZNE ASPEKTY BUDOWY SIECI DRÓG SZYBKIEGO RUCHU W POLSCE Tadeusz Wójcicki}

\section{Projekt sanitarny}

W projektach wodno-kanalizacyjnych dla projektowanych DSR standardowo stosuje się odwodnienie dróg zamiejskich za pomocą rowów drogowych, a w przypadku dróg miejskich - za pomocą kanalizacji deszczowej [Edel 2006].

Ten system odwodnieniowy sprawdza się pod względem ekologicznym, obliczając zgodnie z rozporządzeniem w sprawie warunków, jakie należy spełnić przy wprowadzaniu ścieków do wód lub do ziemi, stężenia zanieczyszczeń w spływach opadowych i sprawdzając, czy na wylotach systemu odwodnienia do odbiorników zewnętrznych wody drogowe nie zawierają substancji zanieczyszczających w ilościach przekraczających $100 \mathrm{mg} / \mathrm{l}$ zawiesin ogólnych oraz $15 \mathrm{mg} / \mathrm{l}$ węglowodorów ropopochodnych. Jeśli te normy będą przekroczone, to stosuje się - w dostosowaniu do uwarunkowań lokalnych - różne urządzenia oczyszczające, np. osadniki (piaskowniki), separatory lub zbiorniki sedymentacyjne.

Drugim problemem ekologicznym systemu odwodnienia dróg jest wzrost ilości odprowadzanych wód do odbiorników zewnętrznych, co wynika ze zamiany pierwotnych powierzchni biologicznie czynnych na szczelne nawierzchnie drogowe. Tutaj standardowym rozwiązaniem jest zastosowanie zbiorników retencyjnych, zmniejszających przepływy maksymalne na wylotach odwodnienia do wód powierzchniowych, czyli do rzek, małych cieków i rowów melioracyjnych.

Ostatnio pojawił się następny problem ekologiczny, związany z wykonanymi symulacjami zmian klimatu w Polsce w okresie nadchodzących 50-100 lat. Te symulacje wskazują że mogą pojawić się znacząco większe natężenia deszczy nawalnych i w rezultacie wyższe ilości dobowych spływów powierzchniowych, prowadzące do większych lokalnych podtopień i powodzi. Aby temu przeciwdziałać, należałoby projektować drogowe urządzenia odwadniające dostosowane do wyższych przepływów i zawierające urządzenia retencyjne o wyższych pojemnościach. Wymaga to zmiany parametrów wejściowych w obliczeniach hydrauliczno-hydrologicznych, co przypuszczalnie nastąpi w najbliższych latach.

Wzrost kosztów budowy urządzeń odwodnieniowych wynikający z powyższych aspektów ekologicznych jest trudny do oszacowania, gdyż nie wiadomo jaką przyjąć sytuację pierwotna, „przed-ekologiczną". Drogowcy stosowali bowiem urządzenia odwodnieniowo-oczyszczające jeszcze przed nastaniem ery ekologicznej, a zastosowanie obecnie większych urządzeń zwiększy co prawda nakłady inwestycyjne, ale jednocześnie zmniejszy koszty napraw w okresie eksploatacji dróg, spowodowanie katastrofalnymi spływami powodziowymi. Można szacować, że wzrost nakładów inwestycyjnych nie jest i nie będzie znacząco duży, gdyż dotyczy drobnych, stosunkowo tanich urządzeń, a ich proekologiczne modyfikacje (powiększenia) nie są i nie będą znaczące.

\section{Projekt elektroenergetyczny}

W projektowaniu DSR uwzględnia się oświetlenie węzłów drogowych i miejsc obsługi podróżnych, a ponadto opracowuje się projekty usunięcia kolizji z istniejącymi sieciami EE. Wpływ czynników ekologicznych na projektowanie branży elektrycznej nie jest duży 
i ogranicza się w zasadzie tylko do dbania, żeby napowietrzne linie wysokiego napięcia, wytwarzające pola elektryczne zagrażające ludziom, lokalizować z dala od zabudowy mieszkaniowej.

Standardowo, w projektach usunięcia kolizji elektrycznych, kabluje się odcinki napowietrznych linii EE kolidujące z droga, co jest korzystne przyrodniczo, gdyż poprawia estetykę otoczenia i bezpieczeństwo użytkowania sieci, likwidując katastrofalne oblodzenia przewodów oraz ich zerwanie w przypadku silnych wiatrów i wiatrołomów.

\section{Projekt zbiorczy (PZT)}

Branża wiodąca, czyli drogowa, oprócz wykonania koncepcji i branżowego projektu drogowego, zajmuje się również scalaniem wszystkich projektów branżowych w jedną spójną całość, której wyrazem graficznym jest plan zagospodarowania terenu (PZT). W tym scalaniu niemałą rolę odgrywają zagadnienia projektowe związane z aspektami ekologicznymi.

Wśród tych aspektów największy dotyczy dodatkowego powiększenia pasa drogowego wskutek zastosowania urządzeń proekologicznych takich jak: przejścia dla zwierząt, zieleń drogowa, urządzenia retencyjne i oczyszczające itp. Liniowa zieleń drogowa powinna mieć szerokość min. $3 \mathrm{~m}$ (rząd pojedynczy z drzew) i o taką szerokość trzeba poszerzyć pas drogowy na jedną albo na dwie strony. Przy przejściach dla zwierząt stosowana jest zgodnie z wymaganiami decyzji środowiskowych specjalna zieleń naprowadzająca, która również wymaga odpowiedniego poszerzenia pasa drogowego. Dużo dodatkowego terenu zajmują ponadto zbiorniki retencyjne, mimo że przy odwodnieniu terenów węzłów drogowych można je zlokalizować wewnątrz pętli łącznic bez dodatkowego zajęcia terenu.

Drugi, poważny aspekt ekologiczny, który należy wziąć pod uwagę przy opracowaniu zbiorczego PZT dotyczy koordynacji między projektem drogowym i mostowym w zakresie niwelety drogi głównej (fot. 8 i fot.9). Na tę niweletę ma duży wpływ masowe stosowanie przejść dla zwierząt. W przypadku dużego zagęszczenia przejść dolnych pod DSR niweleta musi być podniesiona na długich odcinkach do wysokości dochodzącej punktowo do $7 \mathrm{~m}$, w przypadku największego przejścia dolnego dla dużych zwierząt. To podniesienie nie jest ujmowane w kosztach budowy poszczególnych przejść.

\section{Fot. 8. i 9. Proekologiczne podniesienie niwelety DSR na autostradzie A-1 koło Częstochowy}

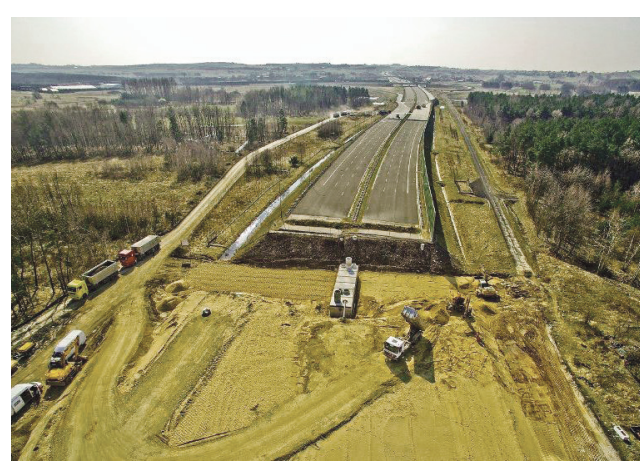

Źródło: GDDKiA

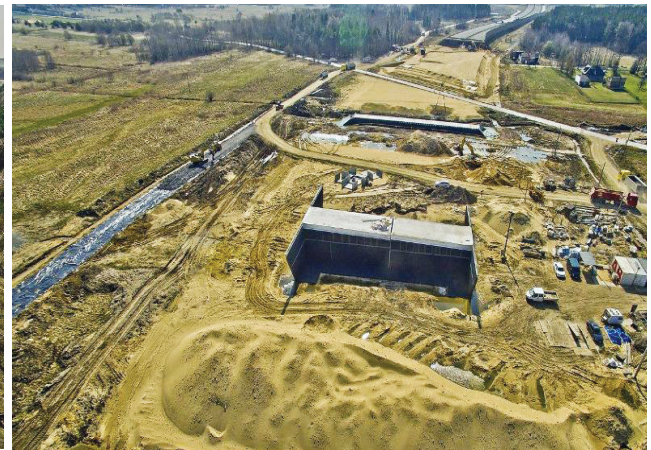

Źródło: GDDKiA 
Z przejściami dla zwierząt wiąże się sprawa koordynacji między lokalizacjami projektowanego oświetlenia drogowego i lokalizacjami przejść dla zwierząt, gdyż światło latarń drogowych odstrasza zwierzęta i nie korzystają one z oświetlonych przejść dla zwierząt. Oznacza to, że np. w rejonie węzłów drogowych oświetlanych standardowo ze względu na bezpieczeństwo ruchu drogowego nie powinno być przejść dla zwierząt, albo odwrotnie, jeśli przejście wpisane do decyzji środowiskowej znajduje się za blisko węzła, to ze względu na jego oświetlenie trzeba przesunąć węzeł dalej od przejścia.

Sprawa oświetlenia nie wywołuje w zasadzie wzrostu kosztów realizacji DSR, a najpoważniejszy koordynacyjny wzrost kosztów związany z aspektami ekologicznymi projektowania wynika z podniesienia niwelety drogowej wskutek zastosowania dolnych przejść dla zwierząt. Zgodnie z danymi zawartymi w tabelach 2. i 3. można założyć, że na obszarach korytarzy migracyjnych i w lasach poza tymi korytarzami zostana, zgodnie z wytycznymi GDOŚ, zastosowane co $500 \mathrm{~m}$ na przemian przejścia dla zwierząt średnich i małych, co powoduje podniesienie niwelety średnio o 1,5 m, czyli koszt wbudowania dodatkowych mas ziemnych w nasyp wyniesie ok. 2,24 mln zł za $1 \mathrm{~km}$. Obszary te obejmują ok. 1589 km dróg, a więc sumaryczny koszt wyniesienia istniejących i planowanych DSR ponad konstrukcję tych przejść wyniesie ok. 3,559 mld zł. Do tego dochodzą dodatkowe koszty wykupu terenu pod poszerzone nasypy, o poszerzeniu średnim o 4,5 m, które można oszacować na ok. 0,358 mld zł, co daje koszt całkowity ok. 3,917 mld zł.

\section{Podsumowanie}

Z powyższego przeglądu ekologicznych aspektów budowy autostrad i dróg ekspresowych wynika, że uwzględnienie przyrodniczych wymagań (zawartych zwykle $\mathrm{w}$ decyzjach środowiskowych) powoduje znaczący wzrost kosztów realizacji sieci DSR. Koszt ten oszacowano powyżej na kwotę ok. 26,0 mld zł, co stanowi ok. 14\% całkowitego kosztu budowy przesądzonej obecnie sieci DSR.

Wśród tych kosztów największe są związane z budową przejść dla zwierząt, oszacowane na ok. 18,4 mld zł (10\%), w tym budowa samych przejść 14,5 mld zł oraz koszty podniesienia niwelety jezdni głównych ok. 3,9 mld zł. Dramatyczną istotność tych kosztów potwierdzają ostatnie krytyczne informacje prasowe [Dolecki 2017; Majszyk 2017; Pałys 2017]. Druga, znaczącą grupę kosztów ekologicznych stanowią koszty związane z proekologicznym wydłużeniem tras drogowych, które oszacowano na 7,6 mld zł (4\%).

Dążąc do ograniczenia tych gigantycznych kosztów zaproponowano zmniejszenie zagęszczenia, czyli zwiększenie rozstawu projektowanych przejść dla zwierząt w poprzek DSR, co zmniejszyłoby koszty budowy tych obiektów z 18,4 mld zł do ok. 2,8 mld zł bez istotnej zmiany oddziaływań DSR na migrujące zwierzęta. Wtedy największy koszt ekologiczny budowy DSR wiązałby się z wydłużeniem ich tras, a tu można jedynie zalecać inwestorom drogowym, aby nie zgłaszali do procedur środowiskowych takich propozycji wariantów przebiegu drogi, które będą powodować znaczące wydłużenie trasy, przekraczające np. 15\% w stosunku do linii prostej (powietrznej). 
Z powyższego przeglądu ekologicznych aspektów budowy DSR wynikają ponadto inne wnioski dotyczące zmiany praktyki planowania, projektowania i budowy tych dróg, niemające jednak tak istotnego wpływu na koszty inwestycyjne. Dotyczy to zwłaszcza nowych zasad projektowania zieleni przydrożnej, urządzeń przeciwhałasowych i systemu odwodnieniowego, a także koordynacji oświetlenia drogowego z lokalizacją przejść dla zwierząt.

\section{Literatura}

Czudek H., Radomski W., 1981, Podstawy mostownictwa, PWN, Warszawa.

Edel R., 2006, Odwodnienie dróg, Wydawnictwa Komunikacji i Łączności, Warszawa.

Dolecki L., 2017, A2 Świecko - Nowy Tomyśl, czyli przejście dla zwierząt średnio co 700 m, Rynek Infrastruktury z 09.04 (http://www.rynekinfrastruktury.pl/wiadomosci/drogi/a2-swieckonowy-tomysl-czyli-przejscie-dla-zwierzat-srednio-co-700-m-58076.html).

Jędrzejewski W., Ławreszuk D., 2009, Ochrona łączności ekologicznej w Polsce, Zakład Badania Ssaków PAN, Białowieża.

Jędrzejewski W., Nowak S., Kurek R., Mysłajek R.W., Stachura K., 2004, Zwierzęta a drogi. Metody ograniczania negatywnego wpływu dróg na populacje dzikich zwierząt, Zakład Badań Ssaków PAN, Białowieża.

Katalog drogowych urządzeń ochrony środowiska, 2002, GDDKiA - IBDiM, Warszawa.

Kondracki J., 2001, Geografia regionalna Polski, Wydawnictwo Naukowe PWN SA, Warszawa.

Kurek R., 2011, Poradnik projektowania przejść dla zwierzą i działan ograniczajacych śmiertelność fauny przy drogach, Generalna Dyrekcja Ochrony Środowiska. Departament Ocen Oddziaływania na Środowisko, Warszawa.

Madaj A., Wołowicki W., 2003, Podstawy projektowania budowli mostowych, Wydawnictwa Komunikacji i Łączności, Warszawa.

Majszyk K., 2017, Jelenie, dziki i zające zawyżaja koszty budowy autostrad, Gazeta Prawna z 01.02. (http://serwisy.gazetaprawna.pl/transport/artykuly/1015899,dzikie-zwierzeta-zawyzajakoszty-budowy-autostrad.html).

Pałys E., 2017, Trzeba 8 mld zt, by wybudować przejścia dla zwierząt, Rynek Infrastruktury z 17.05 .

Podręcznik dobrych praktyk wykonywania opracowań środowiskowych dla dróg krajowych, 2008, EKKOM , Kraków. 


\section{6 | WYBRANE EKOLOGICZNE ASPEKTY BUDOWY SIECI DRÓG SZYBKIEGO RUCHU W POLSCE Tadeusz Wójcicki}

Program Budowy Dróg Krajowych na lata 2008-2012, 2007, Ministerstwo Infrastruktury; http:// mib.bip.gov.pl/transport/strategie-i-programy.html.

Program Budowy Dróg Krajowych na lata 2011-2015, 2011, Ministerstwo Infrastruktury; http:// mib.bip.gov.pl/transport/strategie-i-programy.html.

Program Budowy Dróg Krajowych na lata 2014-2023 (z perspektywa do 2025 r.), 2015, Rada Ministrów; http://mib.bip.gov.pl/transport/strategie-i-programy.html.

Program Budowy Dróg Krajowych na lata 2014-2023 (z perspektywa do 2025 r.). Stan realizacyjny i planowany, 2017, GDDKiA; http://www.gddkia.gov.pl/pl/2547/Sprawdz-na-mapieprzygotowanie-drog-i-autostrad.

Rozporzadzenie Ministra Transportu i Gospodarki Morskiej z dnia 2 marca 1999 r. w sprawie warunków technicznych jakim powinny odpowiadać drogi publiczne i ich usytuowanie, Dz.U. z 1999 r., poz. 430, z późn. zm.

Rozporzadzenie Ministra Transportu i Gospodarki Morskiej z dnia 30 maja 2000 r. w sprawie warunków technicznych jakim powinny odpowiadać drogowe obiekty inżynierskie i ich usytuowanie, Dz.U. z 2000 r., poz. 735, z późn. zm.

Rozporzadzenie Ministra Środowiska z dnia 18 listopada 2014 r. w sprawie warunków, jakie należy spetnić przy wprowadzaniu ścieków do wód lub do ziemi, oraz w sprawie substancji szczególnie szkodliwych dla środowiska wodnego, Dz.U. z 2014 r., poz. 1800.

Ustawa z dnia 16 kwietnia 2004 r. o ochronie przyrody, jedn. tekst, Dz.U. z 2013 r., poz. 627, z późn. zm.

Ustawa z dnia 14 grudnia 2012 r. o odpadach, Dz.U. z 2013 r., poz. 21, z późn. zm.

Ustawa z dnia 7 lipca 1994 r. Prawo budowlane, Dz.U z 2016 r., poz. 290, z późn. zm. 


\section{Selected environmental aspects of building the motorway and expressway network in Poland}

\section{ABSTRACT}

Ecology has become an important element of the design and construction of major national roads in Poland. These environment-oriented changes in road construction have a multifaceted nature which can be observed in numerous examples of more or less successful implementation of new sections of national roads. The aim of this article is to examine the impact of environmental issues on the motorway and expressway network in Poland and the consequences of such a state of affairs.

Ecology influences mainly the design of motorways and expressways (DSR) or, to put it more broadly, the preparation of investments in such roads. This applies in particular to aspects such as the greening of new roads (choosing environmentally sustainable routes) or the construction of wildlife crossings and acoustical barriers. In fact, ecology affects all the aspects of road design and all the relevant industries, but in every industry the impact is different. The influence of ecology on the way large road investments are implemented is smaller than on their design, but is also visible therein, especially in the sometimes detailed prescriptions of environmental permits.

A review of the ecological aspects of the construction of motorways and expressways shows that respecting the environmental requirements normally included in environmental permits results in a significant increase in DSR network costs. This cost has been estimated at approximately PLN 26.0 billion, which accounts for about $14 \%$ of the total.

Among the constituents of these costs, the largest group is connected with the construction of animal passages. Its cost is estimated at about PLN 18.4 billion (10\%), including PLN 14.5 billion spent on the construction of the passages and 3.9 billion on raising the level of the main roadway. The second significant group of environmental costs, estimated at PLN 7.6 billion (4\%), is associated with pro-ecological modification (elongation) of road routes.

In order to reduce these enormous costs, the paper proposes to reduce the density (i.e. increase the spacing) of wildlife crossings across DSR roads which would reduce the costs of building these facilities from PLN 18.4 billion to about PLN 2.8 billion without significantly altering the impact of such roads on migratory animals. If this were implemented, the greatest environmental cost of DSR construction would be route extension; in this case it is only possible to recommend to road investors that they do not report to the environmental permit procedure such variants of the route which entail a significant extension of the route, for example by more than $15 \%$ in relation to a straight line.

Key words: transport, road construction, motorways, express roads, environment

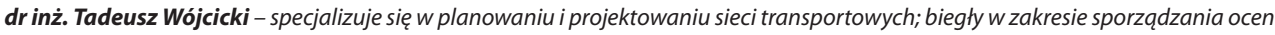
oddziaływania na środowisko; nauczyciel akademicki na Wydziale Architektury Wyższej Szkoły Ekologii i Zarządzania w Warszawie; kontakt do autora: WSEiZ, ul. Olszewska 12, 00-792 Warszawa, tadeuszwojcicki@o2.pl

Tadeusz Wójcicki, Ph. D eng. specializes in the planning and design of transport networks; expert in the field of environmental impact assessment; academic teacher at the Faculty of Architecture at the School of Ecology and Management in Warsaw; contact to the author: WSEiZ, ul. Olszewska 12, 00-792 Warszawa, tadeuszwojcicki@o2.pl
} 